\title{
Effect of Temporal Application of Gypsum on Mineral Uptake and Economically Important Morphometric Traits in Groundnut (Arachis bypogea L) under Rain-fed Conditions
}

\section{Muhammad Jahanzaib ${ }^{1 *}$, Nazakat Nawaz ${ }^{1}$, Muhammad Arshad ${ }^{1}$, Shehzadi Saima ${ }^{4}$, Muhammad Suhaib ${ }^{2}$, Muzammil Husain ${ }^{3}$, Haris Khurshid ${ }^{1}$ and Shahid Ali Khan ${ }^{1}$}

${ }^{1}$ Oilseeds Research Program, CSI, NARC, Islamabad, Pakistan; ${ }^{2}$ Land Resources Research Institute, NARC, Islamabad, Pakistan; ${ }^{3}$ Agricultural Engineering Institute, NARC, Islamabad, Pakistan; ${ }^{4}$ Institute of Pure and Applied Biology, Bahauddin Zakariya University, Multan, Pakistan.

Abstract | Groundnut (Arachis hypogea L) is an important cash crop grown in semi-arid regions of Pakistan. Groundnut is a good source of protein, edible oil, and vitamins. A gradual decline in groundnut yield has been reportedly subjected to various agro-climatic conditions and soil fertility problems. In this study, various regimes of gypsum application and its effect on groundnut yield, morphometric parameters, and minerals $(\mathrm{Ca}, \mathrm{K}, \mathrm{P})$ concentration in root and shoot have been examined. A newly released Pothowar groundnut variety (Variety name) was grown in 3 replications with $5 \mathrm{~m}$ row length using a randomized complete block design. Five different treatments were applied in two split doses i.e. T1 (0 \%:100 \%), T2 (25 \%:75 \%), T3 (50\%:50\%), T4 (75\%:25\%), and T5 (100\%:0 \%) at the time of sowing and pegging compared with Check (T0). Results showed significant differences among treatments for yield and related agronomic traits as well as mineral concentration in response to gypsum application. The highest pod yield $(3522.2 \mathrm{~kg} / \mathrm{ha})$, root biomass $(9.03 \mathrm{~g} / \mathrm{plant})$, and nodules (382/ plant) were observed in treatment T3. The calcium concentration $(0.80 \%)$ in shoots of T3 was the highest. In the present study application of gypsum at the time of sowing and pegging was found to have a positive effect on grain yield and mineral concentration. We recommend that optimum doses of the gypsum should be applied to enhance groundnut yield.

Received | March 16, 2020; Accepted | October 12, 2020; Published | January 31, 2021

*Correspondence | Muhammad Jahanzaib, Oilseeds Research Program, CSI, NARC, Islamabad, Pakistan; Email: m.jahanzaib548@gmail.com Citation | Jahanzaib, M., N. Nawaz, M. Arshad, M. Suhaib, M. Husain, S. Saima, H. Khurshid and S.A. Khan. 2020. Effect of temporal application of gypsum on mineral uptake and economically important morphometric traits in groundnut (Arachis hypogea $\mathrm{L}$ ) under rain-fed conditions. Pakistan Journal of Agricultural Research, 34(1): 1-7.

DOI | http://dx.doi.org/10.17582/journal.pjar/2021/34.1.1.7

Keywords | Agronomic traits, Groundnut, Gypsum, Minerals, Yield

\section{Introduction}

G roundnut or peanut (Arachis hypogaea L.) is the Second most edible oilseed crop after sunflower in terms of production. Groundnut was originated in South America and spread to other parts of the world. Currently, it is grown throughout the globe where more than 100 countries share its cultivation. The top ten producers of groundnut globally are China, India, Nigeria, United States, Sudan,
Myanmar, Tanzania, Argentina, Indonesia, and Senegal (Pandey et al., 2012; Varshney et al., 2013). Groundnut kernel contains $50 \%$ edible oil, $20 \%$ carbohydrates, $25-30 \%$ protein, and $5 \%$ fiber and ash making it a rich human diet (Fageria and Baligar, 1997). Furthermore, it provides minerals including calcium, phosphorus, potassium, and magnesium as well as rich source of vitamins $\mathrm{B}, \mathrm{E}$, and $\mathrm{K}$. It is also rich in thiamine and niacin compared with cereals (Shah et al., 2012). Groundnut can be used either in 
the form of edible oil after processing of the kernels or as a shelled nut. Confectionery items or sauce, groundnut butter, and flour while its haulms are used as animal feed (Ahmad and Rahim, 2007; Shah et al., 2012). As a legume groundnut also enriches the soil via atmospheric nitrogen fixation without draining nonrenewable energies or upsetting the agro-ecological balance (Nadar and Uddin, 2009). Groundnut has a distinctive fruiting habit that plays a vibrant role in the uptake of nutrients particularly $\mathrm{Ca}$. The movement of $\mathrm{Ca}$ takes place from roots to shoots in the transpiration stream via xylem and cannot move through tissues of phloem well. Due to the below ground development of groundnut pods, it cannot receive and transpire $\mathrm{Ca}$ from the plant, so pods must take it directly from the soil (Sumner et al., 1988). For pegging as well as pods formation and pod filling $\mathrm{Ca}$ is a critical element. Deficiency of available $\mathrm{Ca}$ causes embryo abortion leading to a significant reduction in yield (Csinos and Gaines, 1986).

Gypsum or calcium sulphate is a naturally occurring mineral moderately soluble in water (Chen et al., 2005). Gypsum increases the productivity of agriculture crops and improve soil quality (Chen et al., 2005; Tirado-Corbalá et al., 2017) via promoting soil flocculation, reduces surface sealing and crusting, and increase infiltration rate of water (TiradoCorbalá et al., 2017). In infiltrating water, the electrolyte concentration increases due to gypsum application on the soil surface compressing electric double layer and provides calcium to exchange complex where it has selectivity over sodium and magnesium in common soils (Dontsova and Norton, 2002). Gypsum consisting of calcium and sulphur are the most essential macro-elements for plant growth and development. Calcium playing a key role in the superior growth of roots (Watts and Dick, 2014), responsible for strengthening cell wall and root tips development (Tirado-Corbalá et al., 2017). Gypsum application significantly improves yield in crops including sorghum (Rocha et al., 2014), and alfalfa (Tirado-Corbalá et al., 2017).

Being secondary plant nutrient sulphur provide critical support in increasing yield particularly in oil seeds crops. It is critical for sulphur containing amino acids including chlorophyll, cysteine and methionine as well as coenzyme-A synthesis (Kumar and Yadav, 2007). Moreover, it also boosts vegetative growth (Patil et al., 2018). Due to prominent role sulphur it can be regarded as major nutrient. Its absence in early vegetation stage may decline plant growth and as a result pods yield. The gypsum containing little lower concentration of sulphur (15$18 \%$ ), so keeping this in consideration relatively large amounts of gypsum should be applied to meet the optimum requirements of the groundnut. The significance of sulphur in improved yield and quality in groundnut either at sowing or flowering stages has been well documented in the recent past (Abd ELKader, 2013; Elseed et al., 2015; Gashti et al., 2012; Kannan et al., 2017; Pratiwi et al., 2016; Yadav et al., 2015), but none of these reported the comparison of gypsum application both at sowing and flowering stages. The current study was planned with the objective to optimize the gypsum dozes at sowing and flowering stage to increase the groundnut yield and quality.

\section{Materials and Methods}

This experiment was led on the sandy loam soil of oilseed research program at National Agricultural Research Centre (NARC), Islamabad, Pakistan with $33.6701^{\circ} \mathrm{N}, 73.1261^{\circ} \mathrm{E}$ latitude and an altitude of 540 meters above the sea level. Randomized complete block design with three replications and 5 treatments viz. $\mathrm{T}_{1}, \mathrm{~T}_{2}, \mathrm{~T}_{3}, \mathrm{~T}_{4}$, and $\mathrm{T}_{5}$ compared with check was used as experimental design in this study. The treatments were based on the optimum doze of gypsum $(500 \mathrm{~kg} / \mathrm{ha})$. We split the dozes into 2 times, one at the time of sowing and the other at pegging i.e., $\mathrm{T}_{1}(0-100 \%), \mathrm{T}_{2}(25-75 \%), \mathrm{T}_{3}(50-50 \%), \mathrm{T}_{4}(75-$ $25 \%)$, and $\mathrm{T}_{5}(100-0 \%)$ compared to check $\left(\mathrm{T}_{0}\right)$ with zero gypsum application.

\section{Effect of gypsum application on phosphorus and calcium contents}

Phosphorus content/uptake (\%) in roots and shoots was determined by digesting the oven dried plant samples in di-acid $\left(\mathrm{HNO}_{3}-\mathrm{HClO}_{4}\right)$ followed by spectrophotometer at $470 \mathrm{~nm}$ analysis. Calcium content in shoot (\%) was determined from the digested shoot sample via EDTA titration method.

\section{Data analysis}

Data were analysed for analysis of variance (ANOVA) using Statistix 8.1 software while heatmap and box plot were constructed using gg plot 2 and heatmap 2 packages in $\mathrm{R}$ language. 
Results and Discussion

\section{Shoots and roots fresh and dry weight}

Significant increase was observed between fresh and dry weight after gypsum application (Table 1). Among the treatments $\mathrm{T}_{3}$ i.e., $250 \mathrm{~kg} / \mathrm{ha}$ of gypsum application at the time of sowing and $250 \mathrm{~kg} / \mathrm{ha}$ at flowering stage greatly encouraged the root and shoot fresh weight as well as stem and root dry weight compared to other treatments and control (Table 1). Increased plant fresh and dry weight of crops by gypsum application is well-documented in the literature (Rasouli et al., 2013; Rocha et al., 2014), where the reason was increased area of root system, better water and nutrient absorption by plants (Caires et al., 2006). Calcium is an important nutrient promoting better root growth, strengthening cell wall, and root tips development (Toma et al., 1999; Watts and Dick, 2014).

Gypsum application stimulate growth and physiology in groundnut

An increase in number of leaves was observed when relatively low doze of gypsum was applied at sowing stage and high doze was applied during sprouting stage (T2 and T3) as compared to high doze at sowing stage and vice versa. Same trend was observed in roots and shoots length. Maximum shoot and root lengths were recorded with application of $250 \mathrm{~kg} / \mathrm{ha}$ gypsum at sowing and $250 \mathrm{~kg} / \mathrm{ha}\left(\mathrm{T}_{3}\right)$ at sprouting time, significantly superior production was gained compared to other treatments. It was observed that $\mathrm{T}_{3}$ treatment has significantly better effective in promoting overall growth of groundnut plants, which might be due to optimum availability of sulphur. Current findings are supported by Kumar and Yadav (2007) and Patil et al. (2018). It was found that sulphur is vital for protein synthesis in plants being a part of various amino acids. Our results are also in close proximity with Jat and Mehra (2007), Kumar and Yadav (2007) and Rajput et al. (2018).

Boost in calcium uptake by shoots after gypsum application Results showed that all the treatments of gypsum except $T_{1}$ exhibited significant differences $(p<0.05)$ in calcium uptake in groundnut compared with control. Among all treatments significantly higher increase in Ca uptake by shoots was recorded when $50 \%$ of the doze of gypsum was applied at the time of sowing and remaining $50 \%$ of gypsum at flowering stage i.e., $\mathrm{T}_{3}$ (Table 2). The overall increase in Ca uptake was in order of $\mathrm{T}_{3}>\mathrm{T}_{4}>\mathrm{T}_{2}>\mathrm{T}_{5}>\mathrm{T}_{1}$. The higher uptake of $\mathrm{Ca}$ is subjected to optimum amount of gypsum. Findings of Gashti et al., (2012) are backing our results, they too reported increase in $\mathrm{Ca}$ uptake by application of gypsum.

\section{Lift in phosphorus contents after gypsum application}

Significant boost was observed in phosphorus contents of shoots and roots after higher doze of gypsum over control (Table 2). Application of $100 \mathrm{~kg} /$ ha at the time of sowing and $400 \mathrm{~kg} / \mathrm{ha}$ at flowering stage recorded remarkably maximum phosphorus content both in roots and shoots compared with other treatments and control one (Table 2). Highest phosphorus contents in shoot were recorded in $\mathrm{T}_{4}, 75$ $\%$ gypsum applied during sowing and $25 \%$ gypsum applied during sprouting (Figure 1). The increase might be due to favourable effect of the high level of sulphur and calcium. Sulphur might have shown the synergistic effect in increasing the phosphorus uptake (Ismail et al., 2013; Patel and Zinzala, 2018).

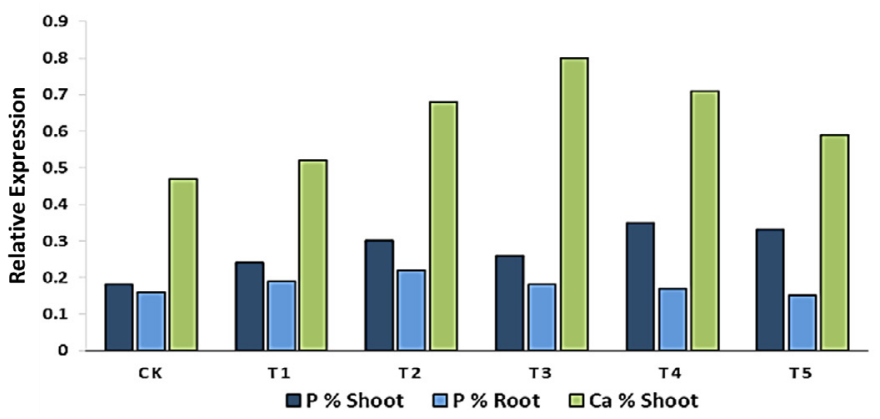

Figure 1: Phosphorus in shoots and roots and calcium in shoots under different levels of gypsum compared to control.

\section{Effect of gypsum application on shelling percentage}

Shelling percentage is one of the most critical features related to flowering pattern, development of kernels, and thickness of shell during the plant growth. The entire yield of groundnut depends on kernels, where nutrition management particularly calcium, distribution of rainfall, and genotype are the elements effecting it directly or indirectly (Gashti et al., 2012). Our findings showed that application of gypsum significantly increased $(\mathrm{P}<0.05)$ the shelling percentage (Table 2). Gypsum is highly soluble in the soil causing easily release and accessibility of calcium content around the pods, where pods can easily use and absorption calcium. Furthermore, gypsum prevents leaching down of other important nutrients as well as help in increase absorption of sulphur and phosphorus that can aid in increase yield of groundnut. The highest shelling percentage obtained 
Table 1: Various morphometric traits estimated after gypsum application in different treatments.

$\begin{array}{llllllll}\text { Treatments } & \text { RFW } & \text { SFW } & \text { L/P } & \text { N/P } & \text { RD W (unit) } & \text { SDW (unit) } & \text { Shelling \% } \\ \text { CK } & 3.33 \pm 0.120^{\mathrm{c}} & 89.7 \pm 6.84^{\mathrm{b}} & 285.33 \pm 14.83^{\mathrm{c}} & 156 \pm 2.081^{\mathrm{d}} & 1.05 \pm 0.04^{\mathrm{b}} & 22.67 \pm 2.61^{\mathrm{b}} & 63.2 \pm 1.2^{\mathrm{a}} \\ \text { T1 } & 4.22 \pm 0.473^{\mathrm{bc}} & 93.35 \pm 3.28^{\mathrm{b}} & 323.33 \pm 7.88^{\mathrm{c}} & 187 \pm 4.72^{\mathrm{c}} & 1.91 \pm 0.20^{\mathrm{ab}} & 24.25 \pm 1.47^{\mathrm{b}} & 65.3 \pm 1.7^{\mathrm{ab}} \\ \text { T2 } & 4.9 \pm 0.477^{\mathrm{b}} & 96.81 \pm 6.38^{\mathrm{b}} & 582 \pm 15.36^{\mathrm{b}} & 249 \pm 9.29^{\mathrm{b}} & 1.87 \pm 0.29^{\mathrm{ab}} & 24.97 \pm 1.92^{\mathrm{b}} & 66 \pm 0.9^{\mathrm{c}} \\ \text { T3 } & 9.03 \pm 0.486^{\mathrm{a}} & 261.26 \pm 2.59^{\mathrm{a}} & 764.67 \pm 12.99^{\mathrm{a}} & 382 \pm 6.42^{\mathrm{a}} & 2.48 \pm 0.70^{\mathrm{a}} & 59.78 \pm 6.89^{\mathrm{a}} & 67 \pm 2.1^{\text {cd }} \\ \text { T4 } & 4.37 \pm 0.255^{\mathrm{b}} & 118.51 \pm 3.24^{\mathrm{b}} & 323.33 \pm 17.52^{\mathrm{c}} & 164.33 \pm 20.25^{\mathrm{cd}} & 1.66 \pm 0.16^{\mathrm{ab}} & 28.23 \pm 5.32^{\mathrm{b}} & 66.7 \pm 1.8^{\mathrm{cd}} \\ \text { T5 } & 4.87 \pm 0.791^{\mathrm{b}} & 118.33 \pm 7.75^{\mathrm{b}} & 279.67 \pm 7.31^{\mathrm{c}} & 114.67 \pm 4.37^{\mathrm{e}} & 1.91 \pm 0.45^{\mathrm{ab}} & 33.19 \pm 7.36^{\mathrm{b}} & 63.4 \pm 1.3^{\mathrm{a}}\end{array}$

CK: Control (TO); RFW: Root fresh weight; SFW: shoot fresh weight; L/P: number of Leaves/plant; N/P: number of nodules/plant; RD W: root dry weight; SDW: stem dry weight; and shelling \%. Values are the mean \pm SEM of 12 values. Means sharing similar letter in a column are non-significant $(P>0.05)$.

Table 2: Discrepancies in nutrient contents and morphometric traits after gypsum application.

$\begin{array}{lllllllll}\begin{array}{l}\text { Treat- } \\ \text { ment }\end{array} & \mathbf{P} \% \text { shoot } & \mathbf{P} \% \text { root } & \text { Ca \% shoot } & \begin{array}{l}\text { Root length } \\ (\mathbf{c m})\end{array} & \begin{array}{l}\text { Shoot length } \\ (\mathbf{c m})\end{array} & \begin{array}{l}20 \text { Pod } \\ \text { length }(\mathbf{c m})\end{array} & \begin{array}{l}\text { Dry pod yield } \\ (\mathbf{g})\end{array} & \begin{array}{l}\text { 100 Kernels } \\ \text { weight }(\mathbf{g})\end{array} \\ \text { CK } & 0.18 \pm 0.004^{\mathrm{d}} & 0.16 \pm 0.003^{\mathrm{d}} & 0.47 \pm 0.008^{\mathrm{d}} & 13.67 \pm 0.33^{\mathrm{b}} & 38.66 \pm 1.20^{\mathrm{ab}} & 60.66 \pm 0.33^{\mathrm{b}} & 2422.2 \pm 11.53^{\mathrm{c}} & 74.67 \pm 0.33^{\mathrm{b}} \\ \mathrm{T} 1 & 0.24 \pm 0.001^{\mathrm{c}} & 0.19 \pm 0.002^{\mathrm{b}} & 0.52 \pm 0.017^{\mathrm{d}} & 15.33 \pm 1.20^{\mathrm{b}} & 42.66 \pm 0.33^{\mathrm{ab}} & 60.33 \pm 0.33^{\mathrm{b}} & 3027.8 \pm 117.37^{\mathrm{b}} & 75.33 \pm 2.40^{\mathrm{b}} \\ \mathrm{T} 2 & 0.3 \pm 0.011^{\mathrm{b}} & 0.22 \pm 0.005^{\mathrm{a}} & 0.68 \pm 0.025^{\mathrm{b}} & 15.00 \pm 0.57^{\mathrm{b}} & 37.00 \pm 1.15^{\mathrm{b}} & 61.33 \pm 0.88^{\mathrm{b}} & 3487.0 \pm 86.14^{\mathrm{c}} & 79.67 \pm 0.88^{\mathrm{a}} \\ \text { T3 } & 0.26 \pm 0.008^{\mathrm{c}} & 0.18 \pm 0.001^{\mathrm{c}} & 0.8 \pm 0.014^{\mathrm{a}} & 18.33 \pm 0.33^{\mathrm{a}} & 43.66 \pm 4.25^{\mathrm{a}} & 63.66 \pm 0.66^{\mathrm{a}} & 3522.2 \pm 131.97^{\mathrm{a}} & 76.67 \pm 1.20^{\mathrm{ab}} \\ \text { T4 } & 0.35 \pm 0.013^{\mathrm{a}} & 0.17 \pm 0.002^{\mathrm{cd}} & 0.71 \pm 0.021^{\mathrm{b}} & 15.17 \pm 1.09^{\mathrm{b}} & 39.66 \pm 1.45^{\mathrm{ab}} & 61.66 \pm 0.33^{\mathrm{b}} & 3253.7 \pm 92.75^{\mathrm{ab}} & 75.33 \pm 0.88^{\mathrm{b}} \\ \text { T5 } & 0.33 \pm 0.009^{\mathrm{ab}} & 0.15 \pm 0.004^{\mathrm{e}} & 0.59 \pm 0.031^{\mathrm{c}} & 14.83 \pm 1.30^{\mathrm{b}} & 39.00 \pm 1.52^{\mathrm{ab}} & 60.66 \pm 0.88^{\mathrm{b}} & 3140.8 \pm 59.60^{\mathrm{b}} & 75.33 \pm 1.20^{\mathrm{b}}\end{array}$

CK: Control (TO); P \% shoot: Phosphorus percentage in shoots; P\% root: Phosphorus percentage in roots; Ca \% shoot; Calcium percentage in shoots. Values are the mean $\pm S E M$ of 12 values. Means sharing similar letter in a column are non-significant $(P>0.05)$.

A
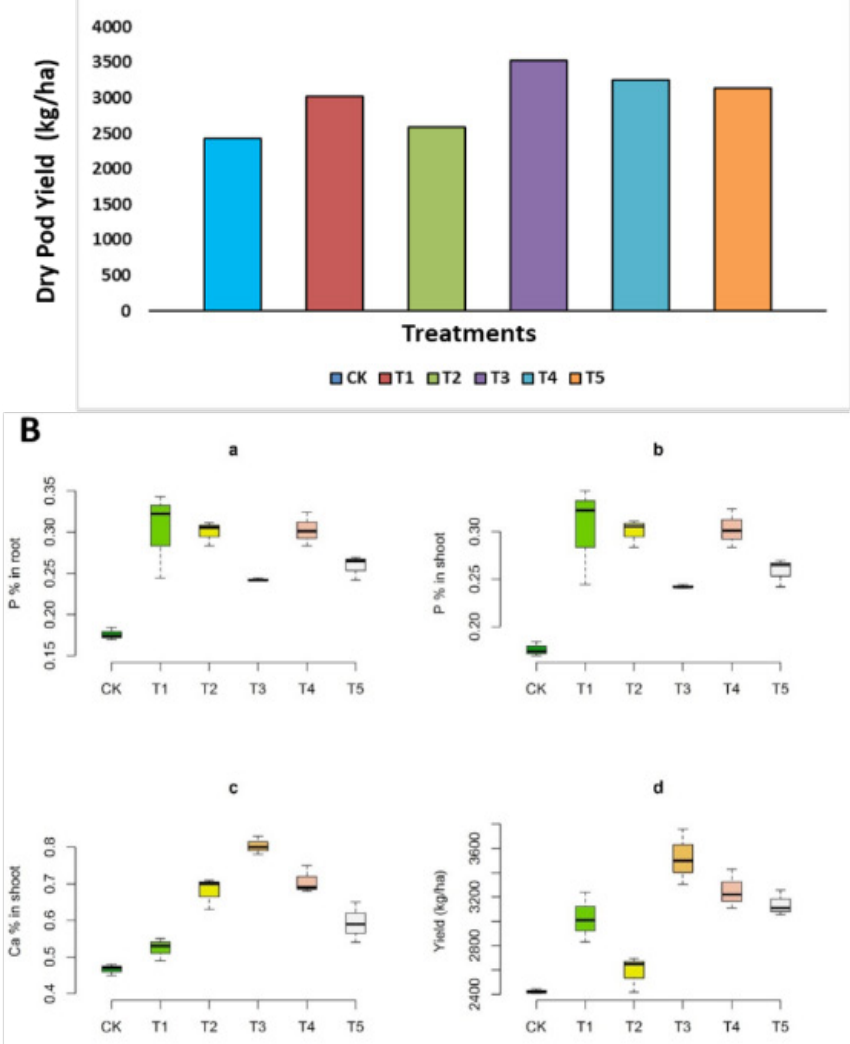

C

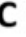

Variation in Treatments

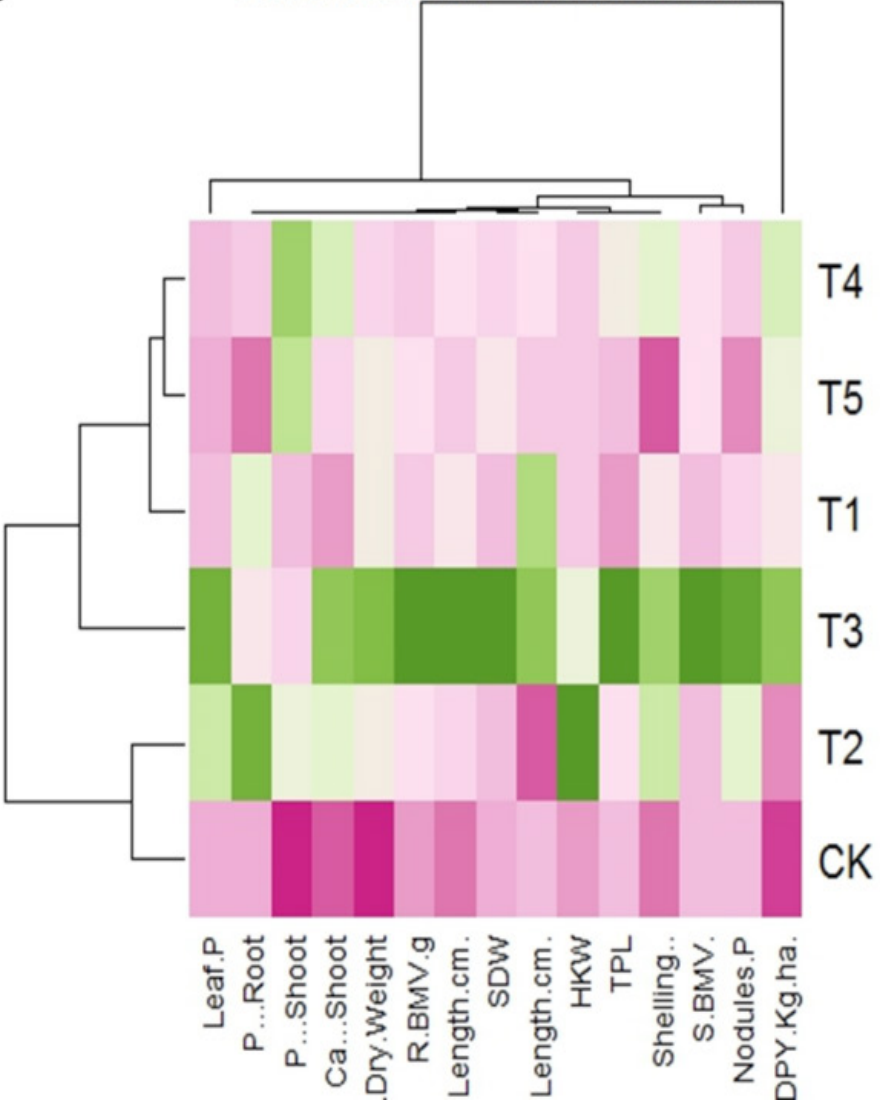

Figure 2: (A) Dry pod yield under different levels of gypsum. (B) Performance of control and treatments for a) P content (\%) in root, b) $P$ content (\%) in shoot, c) Ca content (\%) in shoot and d) grain yield ( $\mathrm{kg} / \mathrm{ha}$ ) in response to gypsum application. (C) Effect of gypsum application showing extent of variation between control and treatments for morphometric traits, $P$ content (\%) in shoots and roots and Ca (\%) in shoots. 
from application of gypsum both at the time of sowing and sprouting $\left(\mathrm{T}_{2}, \mathrm{~T}_{3}\right.$ and $\left.\mathrm{T}_{4}\right)$ as compared to the addition of all gypsum either at sowing or sprouting time (Table 2). This may be due to increase in kernel weight in these treatments as both kernel weight and shelling percentage has a good positive relationship. Application of gypsum to large-seed cultivars is an effective technique in enrichment of kernels size and seed quality, because calcium contents released form gypsum is extra soluble in water (in contrast with other sources of calcium) and pods of groundnut plant can easily absorb it (Gashti et al., 2012).

\section{Positive contribution of gypsum in dry pod length and} yield of groundnut

Appropriate nutrient management of crops is critical to improve the yield. Dry pod yield was significantly diverse among treatments $(p<0.05)$ in current study (Table 2). Results showed that only $250 \mathrm{~kg} / \mathrm{ha}$ of gypsum at sowing time and $250 \mathrm{~kg} / \mathrm{ha}$ at the sprouting time $\left(\mathrm{T}_{3}\right)$ produced longer pods as compared to other treatments and control. It was also noted that use of calcium and sulphur (gypsum) had highly significant effect on yield (Table 2). Among all treatments of gypsum significantly improved yield was documented when gypsum was applied both at sowing and sprouting stages as compared to control (Figure 2A, 2B and 2C). However, maximum yield was recorded after application of $250 \mathrm{~kg} / \mathrm{ha}$ of gypsum at the time of sowing and $250 \mathrm{~kg} / \mathrm{ha}$ at the sprouting time $\left(\mathrm{T}_{3}\right)$. Studies confirmed that groundnut yield increased with fertilizer application including calcium and sulfur i.e., single super phosphate, ammonium sulfate in the alkali soils and gypsum (Macció et al., 2002; Gashti et al., 2012). According to Wiatrak et al. (2006) gypsum application aided to increase yield of groundnut with high potential yield by accumulative availability of $\mathrm{Ca}$ in the fruiting zone in strip-till management systems. They further clarified that yield of groundnut was higher after application of gypsum in comparison to plants without gypsum application. Increased crop productions by application of gypsum have also been reported in studies by Fernandes et al. (2007) and Rasouli et al. (2013).

Gypsum application results in increased 100 kernels weight The trait of 100 kernels weight is an important one to estimate the crop yield. In groundnut it is directly related to the accessibility of crop to optimum amount of nutrients at proper growth stage (Kost et al., 2014). Fluctuations in the availability of essential elements mainly sulphur and calcium around the pods significantly affects the kernels weight (Sushila, 1992; Adams et al., 1993). However, in this study gypsum application had little effect on 100 kernels weight (Table 2). Calcium present in the gypsum may lead to the production of big kernels through speedup of relative growth rate (RGR) of pods or enhance the production of photosynthetic materials which as result increase its transportation towards growing kernels. Highest 100 kernels weight attained when $25 \%$ of gypsum at the sowing time and remaining $75 \%$ at the flowering time $\left(\mathrm{T}_{2}\right)$ was applied compared to others treatments and control (Table 2). Many studies have showed that quality and size of kernels in groundnut increased by the addition of elements like sulphur and calcium (Gashti et al., 2012). Gypsum being a good source of sulphur and calcium for pods in groundnut and should be applied at proper time in optimum amount to get qualitative and bigger kernels.

\section{Conclusions and Recommendations}

The application of gypsum overall improves the fresh and dry weight as well as plant height leading to yield increase in terms of better shelling percentage, pods length and productivity, and kernel weight under normal soil conditions. Application of gypsum either at sowing or flowering time alone did not produce fruitful results. However, split doze of gypsum gave much impressive results. Among all split treatments $\mathrm{T}_{3}$ i.e., $50 \%$ of gypsum at sowing time and $50 \%$ at flowering time affectedly increased all available parameters. We recommend $\mathrm{T}_{3}$ doze of gypsum to increase the agronomic efficiency of groundnut under normal soil conditions.

\section{Acknowledgments}

The authors acknowledge the contribution of Land Resources Research Institute, National Agricultural Research Centre, Islamabad for providing technical support in terms of experimental design and nutrient analysis.

\section{Novelty Statement}

The optimum doses of gypsum i.e. $50 \%$ at sowing time and $50 \%$ at flowering time significantly increase grain yield and mineral concentration. 
Author's Contribution

MJ, NN and MA: Plan, supervised, carried out the experiment, and wrote the manuscript.

MS, MH and SS: Assisted in field layout.

HK and SAK: Helped in statistical analysis, figures drawing, and revision of the manuscript.

\section{Conflict of interest}

The authors have declared no conflict of interest.

\section{References}

Abd EL-Kader, M.G., 2013. Effect of sulfur application and foliar spraying with zinc and boron on yield, yield components, and seed quality of peanut (Arachis hypogaea L.). Res. J. Agric. Biol. Sci. 9: 127-135.

Adams, J.F., D.L. Hartzog and D.B. Nelson. 1993. Supplemental calcium application on yield, grade, and seed quality of runner peanut. Agron. J., 85: 86-93. https://doi.org/10.2134/agronj19 93.00021962008500010018x

Ahmad, N. and M. Rahim. 2007. Performance of promising groundnut, Arachis hypogaea L. varieties for yield and other characters. J. Agric. Res. Pak., 45(3): 185-189.

Caires, E.F., S. Churka, F.J. Garbuio, R.A. Ferrari and M.A. Morgano. 2006. Soybean yield and quality a function oflime and gypsum applications. Sci. Agricola, 63: 370-379. https:// doi.org/10.1590/S0103-90162006000400008

Chen, L., W.A. Dick and S. Nelson. 2005. Flue gas desulfurization products as sulfur sources for alfalfa and soybean. Agron. J., 97: 265-271.

Csinos, A. and T. Gaines. 1986. Peanut pod rot complex: A geocarposphere nutrient imbalance. Plant Dis., 70: 525-529. https://doi. org/10.1094/PD-70-525

Dontsova, K.M. and L.D. Norton. 2002. Clay dispersion, infiltration, and erosion as influenced by exchangeable $\mathrm{Ca}$ and $\mathrm{Mg}$. Soil Sci., 167: 184-193. https://doi.org/10.1097/00010694200203000-00003

Elseed, S., S. Yagoub and I. Mohamed. 2015. Effects of jatropha seed cake (JSC) and different inorganic fertilizers on growth and yield of two groundnut cultivars under three harvesting periods. J. Exp. Agric. Int., pp. 93-103. https:// doi.org/10.9734/AJEA/2015/11027

Fageria, N. and V. Baligar. 1997. Response of common bean, upland rice, corn, wheat, and soybean to soil fertility of an Oxisol. J. Plant Nutr., 20: 1279-1289. https://doi. org/10.1080/01904169709365335

Fernandes, M.B., F.J. Freire and F.G.B. Costa. 2007. Gesso mineral como fonte de enxofre para cana de açúcar. Rev. Caatinga, 20: 109-109.

Gashti, A.H., M.N.S. Vishekaei and M.H. Hosseinzadeh. 2012. Effect of potassium and calcium application on yield, yield components and qualitative characteristics of peanut (Arachis bypogaea L.) in Guilan Province, Iran. World Appl. Sci. J., 16: 540-546.

Ismail, S., S.J. Jani and C. Kosare. 2013. Interaction effect of sulphur and boron on yield, nutrient uptake and quality of soybean grown on Vertisol. Asian J. Soil Sci., 8: 275-278.

Jat, J. and R. Mehra. 2007. Effect of sulphur and zinc on yield, macronutrient content in and uptake by mustard on haplustepts. J. Indian Soc. Soil Sci., 55: 190-195.

Kannan, P., C. Swaminathan and S. Ponmani. 2017. Sulfur nutrition for enhancing rainfed groundnut productivity in typical alfisol of semi-arid regions in India. J. Plant Nutr., 40: 828-840. https://doi.org/10.1080/01904167.2 016.1245329

Kost, D., L. Chen, X. Guo, Y. Tian, K. Ladwig and W.A. Dick. 2014. Effects of flue gas desulfurization and mined gypsums on soil properties and on hay and corn growth in eastern Ohio. J. Environ. Qual., 43: 312-321. https://doi.org/10.2134/jeq2012.0157

Kumar,H. and D. Yadav.2007. Effect of phosphorus and sulphur levels on growth, yield and quality of Indian mustard (Brassica juncea) cultivars. Indian J. Agron., 52: 154-157.

Macció, D., A. Fabra and S. Castro. 2002. Acidity and calcium interaction affect the growth of Bradyrhizobium sp. and the attachment to peanut roots. Soil Biol. Biochem., 34: 201-208. https://doi.org/10.1016/S00380717(01)00174-2

Nadar, K. and M. Uddin. 2009. Agronomic characters of groundnut (Arachis bypogaea L.) genotypes as affected by nitrogen and phosphorus fertilization under rainfed condition. Electron. J. Environ. Agric. Food Chem., 8: 61-68.

Pandey, M.K., E. Monyo, P. Ozias-Akins, X. Liang, P. Guimarães, S.N. Nigam, H.D. Upadhyaya, P. 
Janila, X. Zhang and B. Guo. 2012. Advances in Arachis genomics for peanut improvement. Biotechnol. Adv., 30: 639-651. https://doi. org/10.1016/j.biotechadv.2011.11.001

Patel, A. and V. Zinzala. 2018. Effect of sulphur and boron on nutrient content and uptake by summer groundnut (Arachis hypogeal L.). Pharma Innov. J., 7: 47-50.

Patil, S., S. Ransing, S. Hiwale and S. Rasal. 2018. Effect of phosphorus and sulphur management on growth and yield attributes of linseed. Int. J. Curr. Microbiol. App. Sci., 6: 1147-1155.

Pratiwi, H., N. Aini and R. Soelistyono. 2016. Effects of Pseudomonas fluorescens and sulfur on nutrients uptake, growth and yield of groundnut in an alkaline soil. J. Degraded Min. Lands Manage., 3: 507.

Rajput, R.K., S. Singh,J. Varma, P. Rajput, M. Singh and S. Nath. 2018. Effect of different levels of nitrogen and sulphur on growth and yield of Indian mustard (Brassica juncea (L.) Czern and Coss.) in salt affected soil. J. Pharmacogn. Phytochem., 7: 1053-1055.

Rasouli, F., A.K. Pouya and N. Karimian. 2013. Wheat yield and physico-chemical properties of a sodic soil from semi-arid area of Iran as affected by applied gypsum. Geoderma, 193: 246-255. https://doi.org/10.1016/j. geoderma.2012.10.001

Rocha, I.T.M., F.J. Freire, E.R. Souza, M.B.G.S. Freire, A.V. Silva, D.E.S. Neto and N.M. Sobral. 2014. Mineral gypsum (CaSO4. $2 \mathrm{H} 2 \mathrm{O}$ ), a promoter of biomass production of sweet sorghum. Austral. J. Crop Sci., 8: 1663.

Shah, H., M.A. Khan, T. Azeem, A. Majid and A. Mehmood. 2012. The impact of gypsum application on groundnut yield in rainfed pothwar an economic perspective. https://doi. org/10.35536/lje.2012.v17.i1.a5

Sumner, M., C. Kvien, H. Small and A. Csinos.
1988. On the $\mathrm{Ca}$ nutrition of peanut (Arachis bypogaea L.). I. Conceptual model. J. Fertil. Issues, Manchester, MO 5: 97-102.

Sushila,R.,1992.Effect of major plant nutrients and time of application of calcium and sulphur on growth and yield of rainfed groundnut (Arachis bypogaea L.), Andhra Pradesh Agricultural University Rajendranagar, Hyderabad.

Tirado-Corbalá, R., B.K. Slater, W.A. Dick and D. Barker. 2017. Alfalfa responses to gypsum application measured using undisturbed soil columns. Plants, 6: 29. https://doi.org/10.3390/ plants6030029

Toma, M., M. Sumner, G. Weeks and M. Saigusa. 1999. Long-term effects of gypsum on crop yield and subsoil chemical properties. Soil Sci. Soc. Am. J., 63: 891-895. https://doi. org/10.2136/sssaj1999.634891x

Varshney, R.K., S.M. Mohan, P.M. Gaur, N. Gangarao, M.K. Pandey, A. Bohra, S.L. Sawargaonkar, A. Chitikineni, P.K. Kimurto and P.Janila. 2013. Achievements and prospects of genomics-assisted breeding in three legume crops of the semi-arid tropics. Biotechnol. Adv., 31: 1120-1134. https://doi.org/10.1016/j. biotechadv.2013.01.001

Watts, D.B. and W.A. Dick. 2014. Sustainable uses of FGD gypsum in agricultural systems: Introduction. J. Environ. Qual., 43: 246-252. https://doi.org/10.2134/jeq2013.09.0357

Wiatrak, P.J., D.L. Wright, J.J. Marois and D. Wilson. 2006. Influence of gypsum application on peanut yield and quality. Crop Manage., 5. https://doi.org/10.1094/CM-2006-0223-01RS

Yadav, R., L. Jat, S.N. Yadav, R. Singh and P. Yadav. 2015. Effect of gypsum on growth and yield of groundnut (Arachis hypogaea L.). Environ. Ecol., 33: 676-679. 